\title{
Water equivalent method for city phytostructure of Indonesia
}

\author{
G. Samudro and ${ }^{*}$ S. Mangkoedihardjo
}

Department of Environmental Engineering, Sepuluh Nopember Institute of Technology, Surabaya, Indonesia

Received 13 March 2006; revised 23 May 2006; accepted 7 June 2006; available online 25 June 2006

\begin{abstract}
This paper proposed a simple method and rapid to carry out for organizing city phytostructure. Carbon dioxide sequestration was addressed and referred to population number instead of city area. The unit storage of carbon dioxide, which was nothing less than greenspace area, was determined using equivalent method of determining unit storage of water. For various population number (P) of city area in Indonesia, the greenspace unit (GU) was $29 \mathrm{P}^{-0.3}$ -3.2 , and the greenspace area (GA) was $29 \mathrm{P}^{0.7}-3.2 \mathrm{P}$. Greenspace distribution was preferably on wetlands, river lines, top ground level, and north south direction.
\end{abstract}

Key words: Water, carbon dioxide, greenspace, population

\section{INTRODUCTION}

Greenspace refers to an area that is a green within a city. It can be a street path, an allotment, a garden, a canal path, a children's play area, a cemetery, a wood land, a nature reserve or even wasteland. No one doubt beneficial value of greenspace for life such as creating aesthetic and wildlife habitat, increasing recreational value of lands, conserving water sources, preventing soil erosion and stream sedimentation, reclaiming poorly managed lands, remediating polluted environment, boosting local and regional economies, and many others. Greenspace program had been conducted in most countries and it was intensified to respond increasing level of atmospheric carbon dioxide causing global warming. Moreover, the implementation of a worldwide carbon emissions trading system has prompted the development of plants dedicated to sequestering carbon dioxide into their tissues. Greenspace program exists in Indonesia for years. A ministerial instruction on greenspace dictates the greenspace area should be at least $40 \%$ of city area (IMHA, 1988). Most cities have difficulties on achievement the figure in addition to degreening brought about increasing pressure on the use of land for housing, economic developments and many others. There was often debate on this figure among local government, representative council, and non government organizations in this

*Corresponding author, Email: sarwoko@enviro.its.ac.id Tel.:+6231-594 8886; Fax:+6231-592 8387 issue. Then a government regulation on greenspace replaced the ministerial figure to at least $10 \%$ of city area (Indonesian Regulation, 2002). The new figure was less than designated forest area at least $30 \%$ of region according to Indonesian Regulation (1999). There was no clear reason of deciding the low figure for greenspace, probably there was a lack of reference method. In addition, technical guidelines following the regulation without reference method would come to the difficulties in planning, implementation, monitoring and management of greenspace. Use of simulation models such as multimedia fugacity (Hertwich, 2001; Mackay et al., 1996 and Kirschbaum, 1999, 2000), Century (Kirschbaum and Paul, 2002) may be applicable to determine greenspace area. In addition, many empirical studies that identify plants coverage were emphasized on nutrient removal by means of plants uptake. These may be an approach to develop direct relationship between greenspace and city area, requiring rigorous assessments since many kinds of chemical have to be taken into account. These are valuable methodology resources that can be put as references in technical guidelines. However, central and local governments and their stakeholders should be provided with a simple method in determining greenspace, aiming to develop the same basic of understanding. Therefore the objective of this paper was to create a method of greenspace assessment, relating: (1) carbon dioxide sequestration, (2) population number instead of city 
area, (3) greenspace area and greenspace distribution, representing city phytostructure.

\section{MATERIALS AND METHODS}

Main principles

Method in determining greenspace area in relation with carbon dioxide sequestration and population number was relied on the main principle as follows:

$$
\mathrm{C}_{6} \mathrm{H}_{12} \mathrm{O}_{6}+6 \mathrm{O}_{2} \leftrightarrow 6 \mathrm{CO}_{2}+6 \mathrm{H}_{2} \mathrm{O}
$$

The glucose is typically employed to illustrate the oxidation of chemical energy in the form of organic compounds in biological systems both humans and plants. Plants are capable of making the reaction reversible, representing net photosynthesis. Therefore equation 1 was intended to predict, firstly, the weight of emitted carbon dioxide per capita daily, representing carbon dioxide emission unit (CEU), and secondly, the amount of carbon dioxide which was potentially absorbed by plants per square meter daily, representing carbon dioxide absorption unit (CAU). On these relationship, a greenspace area could be determined according to population number in a given city area.

\section{Water Equivalent (WE)}

Water is essentially a basic need for humans and plants. Accordingly, a number of water molecules (n) were added in both sides of the reaction equation 1 , forming a reaction as follows:

$$
\mathrm{n}_{2} \mathrm{O}+\mathrm{C}_{6} \mathrm{H}_{12} \mathrm{O}_{6}+6 \mathrm{O}_{2} \leftrightarrow 6 \mathrm{CO}_{2}+6 \mathrm{H}_{2} \mathrm{O}+\mathrm{n} \mathrm{H}_{2} \mathrm{O}
$$

Water use fluctuates hourly during one day as well as energy use. Hourly fluctuation of water use is population served specific. Water use fluctuation approaches to constant water supply as population served increases. The water use fluctuation in relation to population number is used to calculate unit volume of water storage. Hence, increasing population number will result in decreasing the unit volume of water storage. It was postulated that hourly fluctuation of water use would be accompanied by hourly fluctuation of carbon dioxide emission, regardless the time of occurrence differs each other. Similar to water use fluctuation, the fluctuation of carbon dioxide emission could be used to calculate unit volume of carbon dioxide storage. Carbon dioxide storage was nothing less than a greenspace area itself, for a given height of plants, instead of concrete or steel container for water. Therefore increasing population number will result in decreasing the unit area of greenspace. These clear that determination of greenspace area was based on the equivalence of determining unit storage of carbon dioxide and unit volume of water. Therefore the method took its name from the letters Water equivalent for determining greenspace area. This was proposed to measure greenspace area in relation to population number.

\section{Greenspace distribution}

Equation 1 was also used to assess greenspace distribution. The availability of water and solar radiation will ensure that plants will absorb carbon dioxide. In particular, solar intensity and sun pathway are natural guidance to where greenspace should preferably be distributed.

\section{Data collection}

All quantitative data were collected by means of literature review and field work. Official reports consisting hourly fluctuation of water use were collected from Public Works Department in Jakarta (Western Java), Yogyakarta (Central Java), and Surabaya (East Java). These were carried out during January, 2003 till April, 2005. The field observation on water use was carried out in addition to the available data on hourly water use for different population number. The field work was conducted in fifteen water service zones covering different population served in the city of Yogyakarta. The field work was carried out starting in October, 2002 and completed in April 2003. The data collected from the field work were aimed to construct more accurate correlation between water storage volume and population served. This was eventually affecting the accuracy of correlation between carbon dioxide storage volume and population number.

\section{RESULTS}

Carbon dioxide emission unit

Right direction of equation 1 represents chemical energy use for human life. To accomplish this, all organic compounds containing chemical energy sources including fuels should be converted into glucose equivalent. An amount of chemical energy is required per capita daily, which can be converted into a number of glucose molecules per capita daily which eventually to calculate carbon dioxide emission per capita daily. Every person's output 
varies according to the amount of exercise taken, the food and fuel consumed, the frequency of transport trip, and many other activities. For the purpose at hand a reasonable figure was that each person needs chemical energy ranging $32 \mathrm{MJ} / \mathrm{cap} /$ day - $36 \mathrm{MJ} / \mathrm{cap} /$ day for developing countries (Krugman and Goldemberg, 1983). Vyas and Sharma (2004) studied on the human energy consumption for meal of about 7.5 MJ/cap/day in rural areas, India. For non-domestic activities it was reasonable to consume three times of the food sources, thus the total average chemical energy use of $34 \mathrm{MJ} / \mathrm{cap} /$ day was applied. Since all chemical energy sources can be stated as glucose equivalent, and one molecule of glucose produces the change in Gibbs free energy of 2.8 MJ, therefore chemical energy needed by human is equivalent to $12 \mathrm{~mol}$ glucose/cap/day, or 2160 g glucose/ cap/day. The complete combustion of the glucose resulted in carbon dioxide emission unit which was rounded to:

$$
\mathrm{CEU}=3200 \mathrm{~g} \text { CO2/cap/day }
$$

\section{Carbon dioxide absorption unit}

Left direction of equation 1 was used to calculate the amount of carbon dioxide which was potentially absorbed by plants per square meter daily. It was difficult to be specific about how much carbon might be gained through transformations of grasslands, pasturelands, croplands, or forestlands. Monteith et al. (1964) studied that over bare soil, the flux varied annually with a summer maximum of about $7 \mathrm{~g} \mathrm{CO} 2 /$ sq-m/day, a winter minimum of $1 \mathrm{~g}$ CO2/sq-m/day. Jo (2000) reported that annual direct carbon uptake by woody plants averaged $6.2 \mathrm{~g} \mathrm{CO} 2 / \mathrm{sq}-\mathrm{m} /$ day for wild lands and $3.7 \mathrm{~g}$ CO2/sq-m/day for urban lands. Annual indirect carbon uptake by trees in urban lands was $5.1 \mathrm{~g} \mathrm{CO} 2 / \mathrm{sq}-\mathrm{m} /$ day. Considering the diversity of plants and environmental conditions, the carbon dioxide absorption unit in tropical conditions is approximated as follows:

$$
\mathrm{CAU}=10 \mathrm{~g} \text { CO2/sq-m/day }
$$

\begin{tabular}{|c|c|c|c|c|c|}
\hline $\begin{array}{l}\text { City } \\
\text { and } \\
\text { year }\end{array}$ & $\begin{array}{l}\text { City area } \\
\text { (Ac) } \\
\text { sq-km }\end{array}$ & $\begin{array}{l}\text { Population number } \\
\text { (P) } \\
\text { million }\end{array}$ & $\begin{array}{c}\text { Greenspace unit } \\
\text { (GU) } \\
\text { sq-m/cap }\end{array}$ & $\begin{array}{c}\text { Greenspace area } \\
\text { (GA) } \\
\text { sq-km }\end{array}$ & $\begin{array}{c}\text { Greenspace area } \\
\text { over city area } \\
\%\end{array}$ \\
\hline \multicolumn{6}{|l|}{ Jakarta } \\
\hline (2000) & 662 & 8.3 & 12 & 98 & 15 \\
\hline (2005) & & 9.0 & 12 & 106 & 16 \\
\hline (2025) & & 11.0 & 11 & 120 & 18 \\
\hline \multicolumn{6}{|l|}{ Surabaya } \\
\hline (2000) & 340 & 2.8 & 18 & 51 & 15 \\
\hline (2005) & & 2.9 & 18 & 52 & 15 \\
\hline (2025) & & 3.2 & 17 & 55 & 16 \\
\hline \multicolumn{6}{|l|}{ Semarang } \\
\hline (2000) & 374 & 1.4 & 23 & 32 & 9 \\
\hline (2005) & $3 / 4$ & 1.5 & 22 & 34 & 9 \\
\hline (2025) & & 1.8 & 21 & 38 & 10 \\
\hline \multicolumn{6}{|l|}{ Surakarta } \\
\hline (2000) & 44 & 0.5 & 33 & 18 & 41 \\
\hline (2005) & 44 & 0.6 & 31 & 18 & 42 \\
\hline (2025) & & 0.9 & 27 & 24 & 55 \\
\hline \multicolumn{6}{|l|}{ Yogyakarta } \\
\hline (2000) & 33 & 0.4 & 35 & 14 & 42 \\
\hline (2005) & & 0.5 & 33 & 18 & 56 \\
\hline (2025) & & 0.8 & 28 & 22 & 67 \\
\hline
\end{tabular}

Table 1: Greenspace area for selected cities in Indonesia using WE method

Predicted volume of emitted carbon dioxide

Hourly fluctuation of water use was provided by water supply authority. In Indonesia there were three fluctuations and typical for city-based population levels. A typical hourly fluctuation of water use for metropolitan cities is presented in Fig. 1 which was used since 1976. Straight line denotes accumulative hourly water use, or in a conversion form was accumulative hourly carbon dioxide emission. Dots line denotes accumulative hourly water supply, or in a conversion form was accumulative carbon dioxide absorption. During one day, a sum of maximum surplus and maximum deficit represents water storage volume, which was nothing less than storage volume for carbon 
dioxide emission. However, storage for carbon dioxide was in the form of a city. The storage calculation method was applied for hourly fluctuation of water use for medium and small cities, and fifteen additional field observation data from Yogyakarta. Result for storage volume of carbon dioxide corresponding to population number is presented in Fig. 2. Metropolitan, medium and small cities were set for population number of $1,0.5$, and 0.01 million respectively. Population number from fifteen zones were ranging from 0.02 million and 0.4 million. Fig. 2 was nothing less than predicted volume of emitted carbon dioxide (VEC) in relation to population number $(\mathrm{P})$ that resulted in the following equation:

$$
\mathrm{VEC}=9 \mathrm{P}^{-0.3}(\%)
$$

By definition, the unit percent of VEC was the percentage of total volume of emitted carbon dioxide by human activities during one day. The unit percent was preferable for flexibility in using weight unit instead of volume unit.

\section{Predicted volume of absorbed carbon dioxide by plants}

Volumetric balance was applied for carbon dioxide emission and absorption. VEC in equation 5 would be distributed to environmental media within a city. The environmental media consists of physical media, i.e. soil, water and air, and plants as biological media. This came up with the proposed Soil, Water, Air, and Plant continuum. The SWAP continuum was responsible for carbon dioxide absorption and should be able to completely counterbalance the emitted carbon dioxide by human activities. Therefore, the following equation was applied as follows:

Volume of emitted CO2 by human activities = Volume of absorbed $\mathrm{CO} 2$ by SWAP continuum

$$
\begin{aligned}
& \mathrm{VEC}=\mathrm{AsHs} / \mathrm{AcHc}+\mathrm{AwHw} / \mathrm{AcHc}+\mathrm{AaHa} / \mathrm{AcHc} \\
& +\mathrm{ApHp} / \mathrm{AcHc}
\end{aligned}
$$

A, H, s, w, a, p, and c denote area, height (or depth), soil, water, air, plants, and city media respectively. AsHs/ AcHc was a proportion of absorbed carbon dioxide by soil over the total volume of absorbed carbon dioxide by SWAP continuum during one day. The same treatment was applied for other media. The depth of soil took the average depth of plant roots zone which was assumed to be $0.5 \mathrm{~m}$. The depth of water was accounted for the active natural aeration which was assumed to be $0.1 \mathrm{~m}$. The height of air was the average plants height which was considered on average of $5.0 \mathrm{~m}$ from the ground level. The city height was a sum of each media depth or height, i.e. 5.6 m. Soil area (As) was city area (Ac) minus water area (Aw). Air area (Aa) was equally the same as city area (Ac). ApHp/AcHc was nothing less than the predicted volume of absorbed carbon dioxide by plants (VACp) and resulted in the following equation:

$$
\text { VACp }=\left[9 \mathrm{P}^{-0.3}-1-0.12 \mathrm{Aw} / \mathrm{Ac}\right](\%)
$$

The last value could be neglected even for waterfullcities, thus the equation was simplified as follows:

$$
\text { VACp }=\left[9 \mathrm{P}^{-0.3}-1\right](\%)
$$

\section{Greenspace unit and greenspace area}

Equation 3, equation 4 and equation 8 were arranged in order to calculate the greenspace unit (GU) by which carbon dioxide is sequestered as follows:

$$
\mathrm{GU}=\left[29 \mathrm{P}^{-0.3}-3.2\right] \text { (sq-m/cap) }
$$

The result shows that in a given city the greenspace unit will be smaller as population number increases. Eventually, GU was multiplied by million of population number, representing greenspace area (GA) in the following equation:

$$
\mathrm{GA}=\left[29 \mathrm{P}^{0.7}-3.2 \mathrm{P}\right](\mathrm{sq}-\mathrm{km})
$$

The last equation clearly shows that greenspace area will be larger as population number increases. Examples for prediction of greenspace area using WE method are provided in the Table 1.

\section{Greenspace distribution}

Equation 1 was the main reference for greenspace distribution in a city. Water availability on land should not be the limiting factor for plants volume to fix carbon dioxide from air. It was clear that greenspace area should be distributed on land where water is naturally available yearly, e.g. wetlands, along river lines, and so on. Plants growth performance is directly influenced by solar radiation. Two factors of this natural energy, i.e. intensity and direction are natural guidance on how phytostructure should be arranged. Firstly, the sun intensity is higher on the top ground level than on the low ground level. From this point of view, it makes sense to distribute greenspace area on the top ground level of a city to ensure photosynthetic energy is not limiting factor. This is supporting the traditional thinking and conventional practice that greening on the top ground level is to maximize rainfall interception into soil at the upstream level. Subsequently, it is maximize groundwater availability and minimize surface runoff which eventually reducing flood in low land area. Secondly, the sun pathway is directed from east to west. 


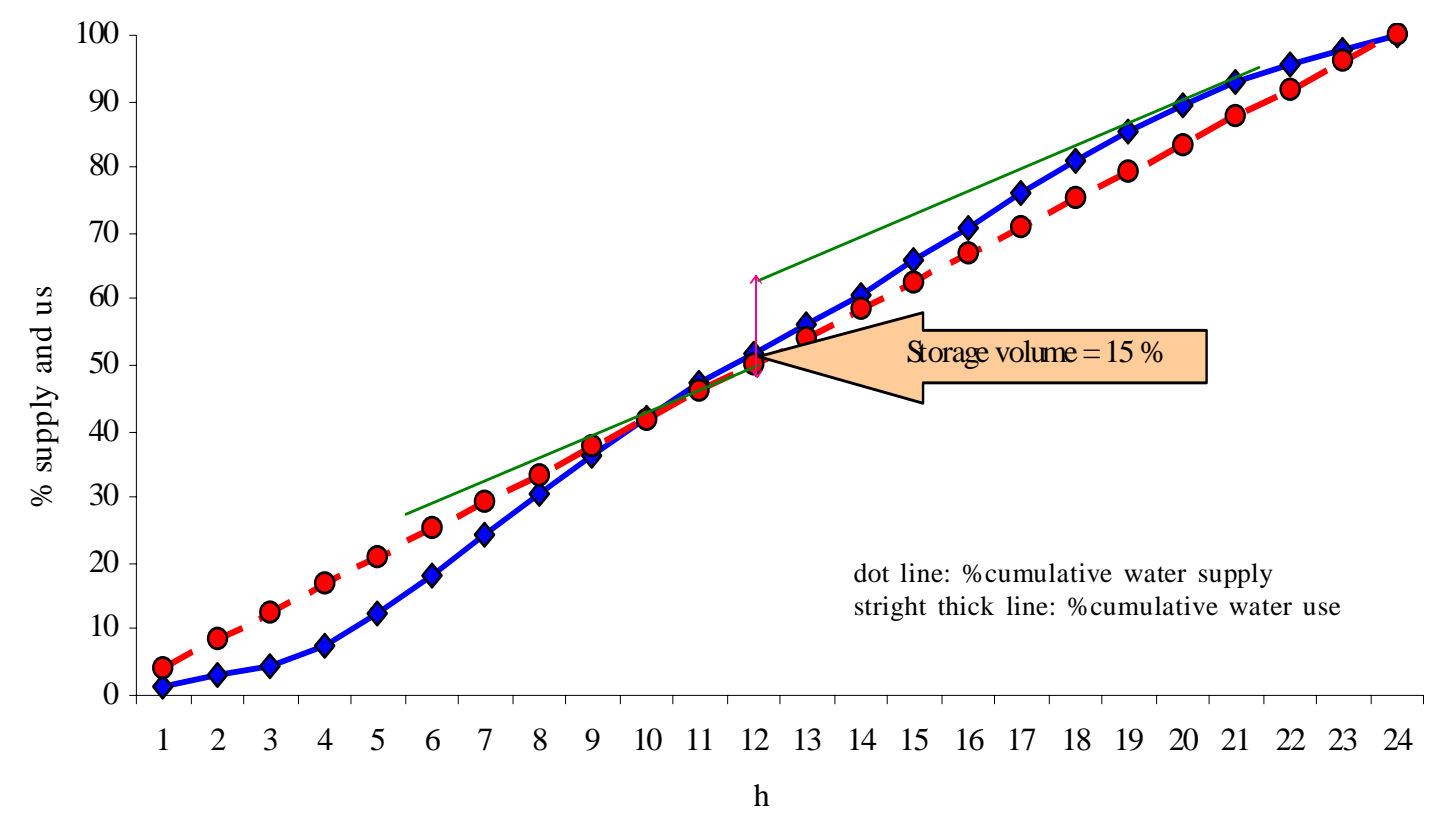

Fig. 1: Typical hourly water use for metropolitan cities

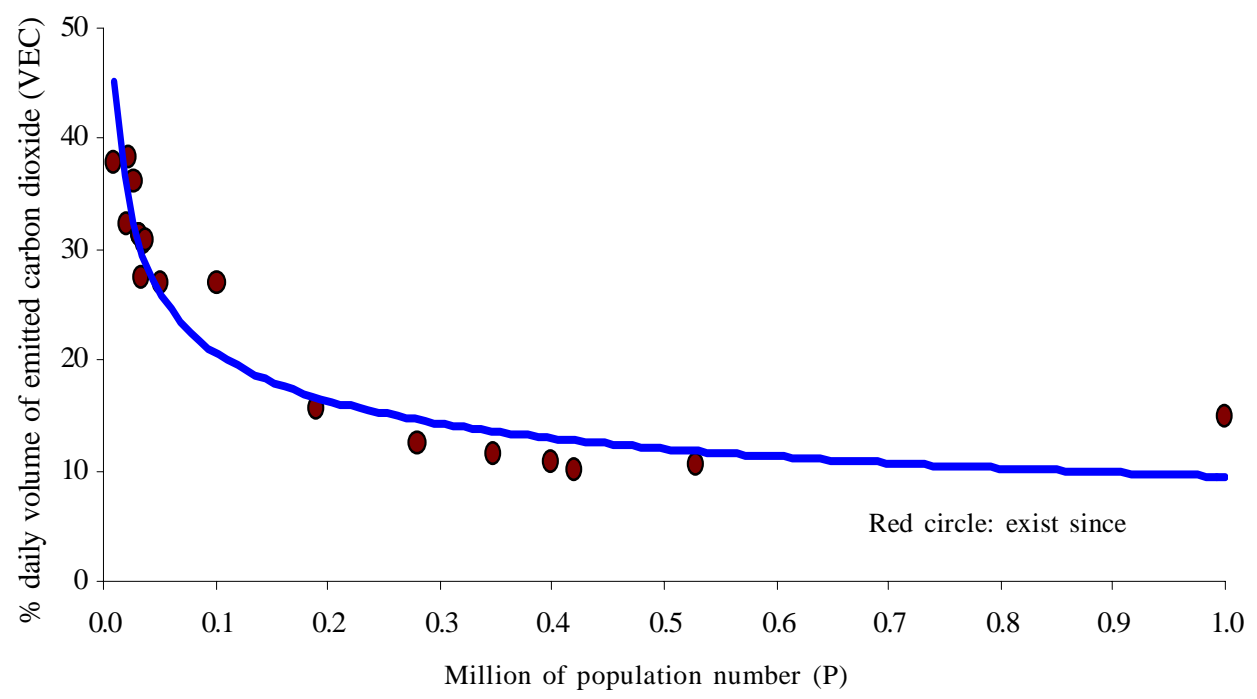

Fig. 2: Predicted volume of emitted carbon dioxide and population number

Plants will be exposed relatively the same solar intensity, since greenspace area is distributed north south instead of other direction, wherever topographical greenspace area is provided. It can be imagine if one drive a car starting at morning and stopping at late afternoon along west east green road, and another day along north south green road. One will choose on driving along north south green road, or vice versa, than west east; simply, because of less of sun exposure on eyes. Unfortunately there was no data on the specific cause of frequently traffic accident, yet a north south greenpace direction probably will minimize the accident. 


\section{DISCUSSION AND CONCLUSION}

Equations 3 and 4 should not be used directly to predict greenspace area even the units were indicated it. For example CEU/CAU equals 320 sq-m/cap and multiplied by population number would result in obtaining greenspace area. This was because of CEU distributed to environment media such as soil, water, and air in addition to plants. In addition, CAU was a "plants capacity" for carbon dioxide absorption, and each of the environment media was capable and responsible for carbon dioxide sequestration. Moreover, carbon dioxide is emitted not only by human activities, but also non-human activities such as animals, microbes and natural activities. These nonhuman sources are counterbalanced by non-plants absorbers such as phytoplankton in wetlands, rivers and even ocean for coastal cities. In addition, human activities tend to increase of using energy as well as increasing population number, representing humans and plants will be the main factors for CEU and CAU respectively. Accordingly, the CEU/CAU value will vary in time for a given city as well as for different cities. Table 1 shows that there was no consistency of using greenspace area based on city area. There were cities having greenspase area over city area more than the regulated greenspace and other were less, suggesting the regulation was not fair. This was the drawback of grenspace-based city area. In conclusion, the principle methodology was to assign water use to predict carbon dioxide sequestration by plants. Water use equivalent method was dependent on population number instead of city area. This suggests no single quantitative greenspace area could be generalized for all cities that should be regulated, except greenspace distribution that follows natural guidance.

\section{ACKNOWLEDGEMENT}

The authors wish to thank Miss Kapi Hapidah at Drinking Water Enterprise (PDAM) Yogyakarta for her thesis assignment on water use observation under the direct supervision of the corresponding author in 2002.

\section{REFERENCES}

Government Regulation, (1999). Indonesian Regulation No. 41. Forestry. Original term: Undang-undang Republik Indonesia No. 41, Tahun, tentang kehutanan.

Hertwich, E. G., (2001). Fugacity superposition: a new approach to dynamic multimedia fate modeling. Chemosph., 44, 843853.

Indonesian Regulation, (2002). Government Regulation No. 63. City forests. Original term: Peraturan Pemerintah No. 63, Tahun, tentang Hutan Kota.

IMHA, (1988). Instruction of Ministry of Home Affair No. 14, Greenspace in urban area. Instruction of Ministry of Home Affair Original term: Instruksi Menteri Dalam Negeri Nomor 14. Tahun, Tentang Penataan Ruang Terbuka Hijau Di Wilayah Perkotaan.

Jo, H. K. (2000). Carbon flows and the role of greenspace in urban ecosystem for Chuncheon, Korea. Urban ecology: The eastern and western perspectives, symposium on urban ecology at the 2000. Ecological Society of America Annual Meeting in Snowbird, Utah. August $7^{\text {th. }}, 2000$.

Kirschbaum, M. U. F. and Paul, K. I., (2002). Modelling C and $\mathrm{N}$ dynamics in forest soils with a modified version of the CENTURY model. Soil Biol. Biochem., 34, 341-354.

Kirschbaum, M. U. F., (1999). CenW, a forest growth model with linked carbon, energy, nutrient and water cycles. Ecol. Model., 181, 17-59.

Kirschbaum, M. U. F., (2000). CenW: a generic forest growth model. New Zealand J. Forest. 45, 15-19.

Krugman, H. and Goldemberg, J., (1983). The energy cost of satisfying basic human needs. Tech. Forecast. Soc. Change., 24, 45-60.

Mackay, D., Di Guardo, A., Paterson, S., and Cowan, C. E., (1996). Evaluating the environmental fate of a variety of types of chemicals using the EQC model. Environ. Toxicol. Chem., 15, 1627-1637.

Monteith, J. L., Szeicz, G., and Yabuki, K., (1964). Crop photosynthesis and the flux of carbon dioxide below the canopy. J. App. Ecol., 1 (2), 321-337.

Vyas, N. and Sharma, A., (2004). Human energy consumption for meal preparation in rural aras of himachal pradesh, J. Human Ecol., 15 (1), 1-3.

Williams, M., Law, B. E., Anthoni, P. M., and Unsworth, M. H., (2001). Use of a simulation model and ecosystem flux data to examine carbon-water interactions in ponderosa pine. Tree Physiol., 21, 287-298. 


\section{AUTHOR(S) BIOSKETCHES}

Samudro, G., B. Eng., M. Eng., student in Environmental Engineering Post Graduate Programme, Sepuluh Nopember Institute of Technology (ITS), Surabaya, Indonesia.

Email: ganjarsamudro@gmail.com

Mangkoedihardjo, S., B. Eng., M.Sc., E.S., Ph.D., is a senior lecturer in Environmental Engineering Department, and the head of the Laboratory of Environmental Technology, Sepuluh Nopember Institute of Technology (ITS), Surabaya, Indonesia. Email: sarwoko@enviro.its.ac.id

This article should be referenced as follows:

Samudro,G. and Mangkoedihardjo, S., (2006). Water equivalent method for city phytostructure of Indonesia. Int. J. Environ. Sci. Tech., 3 (3), 261-267. 